UDC 330.322:316.422:658.64

JEL Classification: D92, M19, I1 1

DOI: 10.15587/2706-5448.2021.229778

Article type «Reports on Research Projects»

\section{Iaroslava Levchenko, Nataliya Solopun}

\title{
RESEARCH OF THE ROLE OF INVESTMENT AND INNOVATIVE ACTIVITIES IN THE PROCESS OF MANAGEMENT OF MEDICAL INSTITUTIONS
}

The object of research is investment and innovation activity as a component of modern medical management. One of the problematic points is that the transformational transition from outdated management methods has caused the need to form a new management system, which should be implemented in all spheres of society's functioning. Even in those that were regulated only by government agencies. In particular, it is possible to talk about the health sector. But today, far from all medical institutions can show an effective management system of an institution. Therefore, there is a need to introduce a «new management» of health care institutions based on the use of investment and innovation tools.

In the course of the study, the following scientific methods were used, as a method of theoretical analysis when studying the foundations of the functioning of health care institutions and the approaches of neoinstitutional theory and the theory of transaction costs when studying the activities of institutions of medical infrastructure. As well as methods of theoretical analysis, comparison and generalization for a general analysis of the issue and for determining the properties of the management system of medical institutions.

The proposed work examines the development of the market for medical services on the example of Ukraine, along with state-guaranteed free medical care, in a correct and fair balance. Conclusions are drawn about the need to move from a system of exclusively budgetary financing of health care to a new budgetary and insurance model based on compulsory insurance. The importance of the search and development of investment funds, which will become the basis for the creation of a high-tech modern base of medical equipment and medical technologies, has been investigated.

Thanks to the research results, modern healthcare institutions will be able to more reasonably approach the issue of organizing their own innovative and investment activities; if implemented correctly, it will allow them to get additional profit and improve the institution's management system.

Keywords: management of healthcare institutions, transformation process, medical institution, investment and innovation activity, insurance medicine.

\section{How to cite}

Levchenko, I., Solopun, N. (2021). Research of the role of investment and innovative activities in the process of management of medical institutions. Technology Audit and Production Reserves, 2 (4 (58)), 16-19. doi: http://doi.org/10.15587/2706-5448.2021.229778

\section{Introduction}

Continuous improvement of the management process of healthcare institutions is an integral part of modern management both at the state and local levels. The transformation process continues, which prompts medical institutions, as well as institutions and organizations of other sectors of the state's economy, to become on the rails of market economy.

The experience of different people has seen the presence of several models of organizing the protection of the health of citizens. The generally accepted classification of health care systems in the vast majority of countries provides for the division into three basic categories, that is, public, insurance and private medicine. But the issue of «health administration» is in constant development, so one can observe the simultaneous transformation of all three models, but sometimes with a clear predominance of one. But any model, to one degree or another, requires the use of modern management methods and the implementation of effective investment and innovation activities.

It should be noted that the imperfections of health systems in different countries can manifest themselves in different ways. The United States of America is facing continued increases in health care costs compared to other countries. But in a number of countries where state control 
over health care prevails, citizens are most likely to face the so-called «waiting list», service rationing, restrictions on the choice of a doctor and other obstacles in the field of medical care, and the like. Almost everywhere there is a reduction in the budget allocated to health care, tax increases and cuts in social benefits and the like. But it should be noted that there are cases when the health care system shows positive results, in particular, through the introduction of modern management methods, abandonment of centralized state control and focus on market laws and market mechanisms. Therefore, it is relevant to study the role of investment and innovation activities in the management of medical institutions, which will be considered in this work on the example of Ukrainian healthcare institutions.

Reforming the medical system of Ukraine provides a list of opportunities for the formation of a modern medical institution that carries out not only medical activities, but also activities to attract investment funds in order to improve their own practice with the help of the latest, innovative technologies. Such technologies should be implemented at all levels of the institution's functioning and relate to all spheres of activity of a medical institution, in particular, management.

The issue of management of medical institutions was considered by many scientists, for example, the authors of works [1-3], and other specialists, who noted the important role of medical management in the modern economic and social life of the state. The issue of investment and innovation activities of medical institutions is in the field of view of a number of authors. In particular, the author of the study [4], among the sources of funds for innovative projects, proposed financing health care institutions using such an instrument as an investment fund for the development of health care institutions and the like. In work [5], the author proposes a classification of innovations in the health care sector of Ukraine and highlights the structural and functional characteristics of the innovative development of the health care sector. But it should be noted that, nevertheless, the issue of investment and innovative activities of medical institutions has not been sufficiently developed and require further processing.

Health systems are becoming more complex, including the provision of public and private health services, primary health care. Health systems are constantly evolving to adapt to epidemiological, demographic and social shifts. New technologies and political, economic, social and environmental realities are creating a complex order of the day for global health [6]. There is an opinion in the world about the need to reform the health care system, in particular, to provide an opportunity to receive the full range of treatment services for a wide range of people with low incomes [7]. For example, the authors in [8] examine the experience and knowledge of health care in India as a country with a so-called «emerging economy». The paper examines innovations that can lead to real success in healthcare, explores cost-effective and steel solutions, as well as the latest innovations in healthcare from global and Indian perspectives, and the like. The authors emphasize the importance of a lean approach to health and innovation, and consider low-cost mass solutions that improve access to health care.

Thus, the object of research is investment and innovation activity as a component of modern medical management.
And the aim of research is to consider the role and place of investment and innovative activities of medical institutions in the process of managing these business entities.

\section{Methods of research}

The following scientific methods are used:

- method of theoretical analysis in the study of the foundations of the functioning of healthcare institutions; - approaches of neoinstitutional theory and the theory of transaction costs in the study of the activities of medical infrastructure institutions;

- methods of theoretical analysis, comparison and generalization for a general analysis of the issue and for determining the composition and properties of the management system of medical institutions.

\section{Research results and discussion}

The current stage in the development of economic relations is the result of the transformation processes that have taken place in recent decades. Changes in the socio-economic sphere and the focus on creating a promising medical postponement encourage medical institutions to develop such management methods that were demanded by the state within the framework of relevant social programs. In addition, it is promising for potential investors who can make financial investments in the innovative activities of medical institutions. Modern health care management, like the management of other spheres of the national economy, must take into account the needs of society, and the further development of the management system in this area of public life should be carried out on the principles of social responsibility and ethics. For the introduction of the latest management methods, along with the introduction of the newest methods of direct treatment, certain funds are needed, which should be directed to the development of this issue.

The viral epidemic that humanity faced in 2020 has highlighted the high importance and need for increased investment in medical innovative technologies. Of course, the sphere of providing medical services has always been a rather attractive object in terms of investments. But the challenges actively stimulate further scientific developments and solutions for diagnostics, treatment, and improving the quality of human life too. The Ministry of Finance of Ukraine notes that improving the health of the population of Ukraine by providing access to basic medical services is an important area of changes in health policy [9]. And further development of affordable medical care within the framework of modern processes of reforming the industry is an important task of the state.

A medical service is certain actions of medical personnel in relation to the consumer of medical practice - a patient with mutual consent and agreement [10].

A medical service, being a product of the market, differs sharply from any other product or service and is characterized by a number of its own characteristics:

- does not exist before the start of production;

- laborious and does not have a clear cost until the end

of the execution;

- not material;

- difficult to calculate;

- personified;

- intellectually dependent on the service provider; 
- quality of the service is variable even if it is performed by the same doctor;

- attitude towards the provided service is based on the subjective attitude of the provided service and depends on the characteristics of the consumer, etc. [11].

But the growth rates of the Ukrainian market of medical services today are characterized by a further increase in demand for paid medical services, despite the legislatively declared principle of free medical care [12]. The volume of the medical services market is growing, in particular, due to the emergence of new private health care institutions.

In general, medical care is provided free of charge at the expense of the budget in health care institutions and individual entrepreneurs who are registered and obtained, in accordance with the procedure established by law, a license to carry out economic activities in medical practice. They and the main administrators of budgetary funds have concluded agreements on medical services for the population.

The cost of a health care service is calculated based on the cost structure required to provide the service in accordance with industry standards in the health care sector.

An overview of the income generation scheme for medical institutions is shown in Fig. 1 [13].

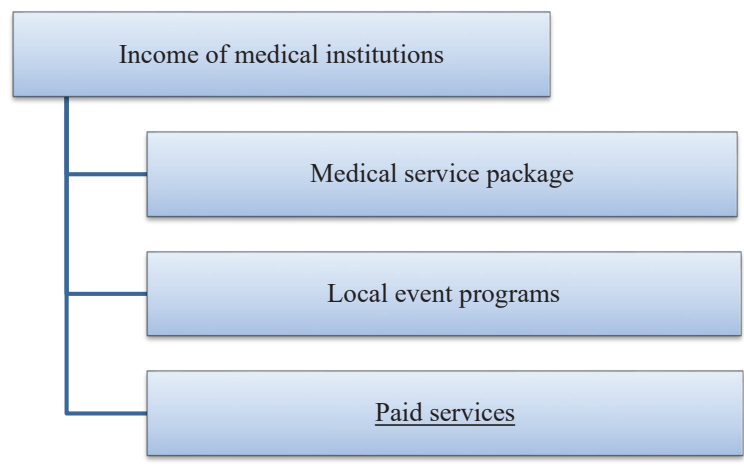

Fig. 1. The scheme of income generation of medical institutions

The costs of providing medical services include the main and additional incentives for personnel, incentives for young professionals and specialists providing primary health care, including in remote settlements. In addition, it is necessary to purchase equipment that will improve the quality of preventive and consultative examinations and the implementation of treatment.

The list of medical services that are paid is contained in the decree of the Cabinet of Ministers of Ukraine dated September 17, 1996 No. 1138. This list is wide enough and includes not only medical, but also other services that medical institutions can provide, in particular for the implementation of economic and production activities, for example, the services of higher medical schools. Among the paid services, there are, in particular, the following:

- dental care;

- prosthetics;

- vision correction;

- cosmetology assistance;

- wellness massage;

- laboratory, diagnostic and consulting services without a doctor's referral, etc. [14].

Of course, the implementation of such services requires appropriate modern technological equipment, materials, payment for personnel training in the latest technologies, and the like. Therefore, the search for investment funds for the implementation of modern innovative services is a permanently important issue for medical institutions ready to offer quality services to the market.

In addition, the example of developed countries testifies, for example, to such a phenomenon as the so-called «university clinic». The University Clinic is a medical institution that combines the following areas in its activities: the provision of medical services, scientific research and training of specialists. In this type of institution, not only modern equipment should be concentrated, but also the best models of rational management, financing and quality control of medical care, and the like. These are new opportunities for scientific research that meet modern world requirements, the introduction of innovative methods into practice, as well as new horizons of international cooperation with leading scientific and medical institutions (university clinics) and specialized medical associations [15].

The presence of a university clinic indicates the high status of the institution (both medical and educational), high scientific depth, since science goes along with the provision of medical services. Therefore, the founding of such an institution will also require certain investment investments, because an educational institution (university) is not always able to establish such a unit on its own. And in terms of income, the university clinic can become a significant source of additional funds for the further development of both the clinic and the university.

The above example once again emphasizes the important place of investment and innovation activities in the management structure of a medical institution.

The authors in [16] argue that a well-designed health management program (in different directions) can lead to monetary savings for the organization and the like.

The general management structure of an organization of any direction presupposes the presence of «hard» and «soft» controls. «Hard» controls (strategy, structure, systems) reflect the formal side of the organization and are fixed in various documents of each specific company. «Soft» elements of management (the sum of skills, common values, style, staff composition) reflect the informal side of the organization (Fig. 2) [17].

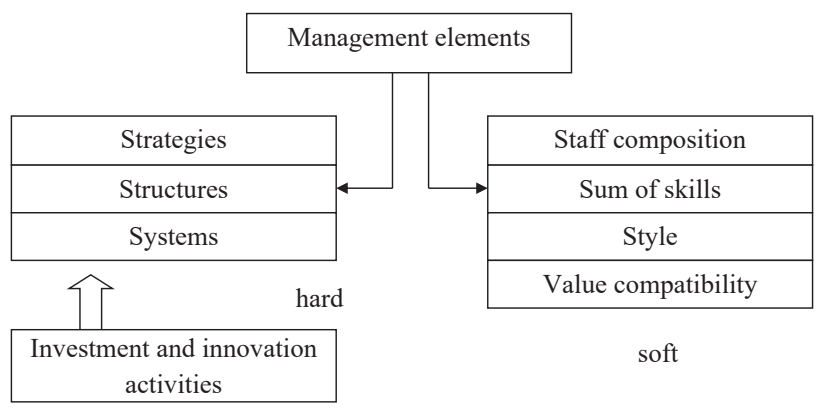

Fig. 2. The scheme for the formation of an effective and efficient approach to enterprise management

On the proposed scheme, among the «hard» components of the organization's management, a special place of investment and innovation should be noted.

In the general list of components of the management of organizations, the following areas of activity can be distinguished:

- economic activity;

- organization and logistics; 
- marketing activity;

- business planning;

- accounting and auditing;

- financial activities;

- investment and innovation activities.

On the issue of health insurance, which can be considered as the consumer's path to the market of services, are not included in the list of free medical services guaranteed by the state, the potential for the further development of this area in Ukraine is significant.

Health insurance allows for a more rational use of funds intended to ensure health care, and at the same time improve the quality of these services and the level of provision of them to the population. Its main participants are insurance companies that offer relevant services, policyholders (individuals and legal entities), insurance intermediaries, assistance companies, medical institutions of various forms of ownership, etc. [18].

Among the options for reforming the medical sector for Ukraine is the transition from a system of exclusively budgetary financing of health care to a new budgetary and insurance model (mixed), based on compulsory insurance. The idea of introducing compulsory health insurance has recently reached a qualitatively new level. United Nations (UN) Secretary-General Ban Ki-moon has declared the need to ensure universal access to quality health care by introducing universal health insurance. This position may become an impetus for the active promotion of compulsory health insurance in Ukraine [19].

With the proper implementation of health insurance, the population of the country will receive wider access to modern medicinal services, emphasizes the need to introduce investment and innovation activities in the organizational activities of health care institutions.

\section{Conclusions}

So, in the course of the proposed study, the important role of introducing investment and innovation into the management activities of a medical institution was noted. The event will allow these institutions to expand the list of offered services and provide them at a high world level. Among the tools that may be useful in the implementation of this issue is, in particular, health insurance, which will provide the population with the opportunity to receive high-quality medical services that are not included in the list of services, the provision of which is guaranteed by the state. All this emphasizes the need for a constant search for investment funds that will become the basis for creating a high-tech modern base of medical equipment and treatment technologies. Among the elements of modern management, the role of investment and innovation activity is indicated as a necessary modern component of such a complex process as managing an organization.

\section{References}

1. Alsharf, I. A. M. (2020). Forming the mechanism of performance management for medical companies and institutions. Odessa, 239.

2. Shevchenko, R. A., Matushak, A. V., Denysenko, Ya. A. (2017). Medychnyi menedzhment $\mathrm{v}$ ekstrenii medytsyni yak zaporuka efektyvnosti roboty systemy. Ekstrena medytsyna: vid nauky do praktyky, 4 (25), 23-33.
3. Örtenblad, A., Löfström, C. A., Sheaff, R. (2015). Management Innovations for Healthcare Organizations: Adopt, Abandon or Adapt? Routledge, 462. doi: http://doi.org/10.4324/9781315739786

4. Holovash, O. (2019). Financial support for the development of healthinstitutions of Ukrainian Railway JSC. Visnyk ekonomiky transportu $i$ promyslovosti, 68, 253-260. Available at: http:// webcache.googleusercontent.com/search?q=cache:lPEMp019M SEJ:btie.kart.edu.ua/article/download/188429/189337+\&cd= $1 \& \mathrm{hl}=\mathrm{ru} \& \mathrm{ct}=\mathrm{clnk} \& \mathrm{gl}=\mathrm{ua}$

5. Petruch, O. (2018). Innovative development of Ukraine's healthcare sector. Ekonomika ta derzhava, 11, 107-110. doi: http:// doi.org/10.32702/2306-6806.2018.11.107

6. Figueroa, C. A., Harrison, R., Chauhan, A., Meyer, L. (2019) Priorities and challenges for health leadership and workforce management globally: a rapid review. BMC Health Services Research, 19 (1). doi: http://doi.org/10.1186/s12913-019-4080-7

7. Senkubuge, F., Modisenyane, M., Bishaw, T. (2014). Strengthening health systems by health sector reforms. Global Health Action, 7 (1), 23568. doi: http://doi.org/10.3402/gha.v7.23568

8. Singh, V. K., Lillrank, P. (Eds.) (2015). Innovations in Healthcare Management. Cost-Effective and Sustainable Solutions. Productivity Press, 456. doi: http://doi.org/10.1201/b18113

9. Pokazniki derzhavnogo biudzhetu na 2022-2023 roki. Available at: https://mof.gov.ua/storage/files/p DB.pdf Last accessed: 11.02.2021

10. Litvak, A. (2012). Stan rynku medychnykh posluh v UkrainiStan rynku medychnykh posluh v Ukraini. Aktualni problemy derzhavnoho upravlinnia, 1, 101-106. Available at: http://nbuv. gov.ua/UJRN/apdyo_2012_1_30

11. Marova, S. F., Vovkf, S. M. (2017). Medical service as a medical product. Derzhavne upravlinnia: udoskonalennia ta rozvytok, 4. Available at: http://www.dy.nayka.com.ua/?op=1\&z=1056

12. Borshch, V. I. (2020). Healthcare market in Ukraine: the modern conditions and trends of its development. Market Economy: Modern Management Theory and Practice, 19 (1 (44)), 140-159. doi: http://doi.org/10.18524/2413-9998.2020.1(44).198360

13. Standarty vytrat u rozrizi haluzei yak osnova efektyonoho finansovoho upravlinnia dlia riznykh typiv OTH (2020). Available at: https:/ www.ua.undp.org/content/ukraine/uk/home/library/recovery-andpeacebuilding/financial-management-for-ATC-guide.html

14. Onyshchenko, V. (2021). Platni medychni posluhy 2021. Available at: https://www.golovbukh.ua/article/7600-platn-medichnposlugi?from $=$ PW_click_desktop_nedoreg\&id $=7600 \&$ refreshPr ofile=Y\&tail=platn-medichn-poslugi\#anc_2

15. Ternovaia, S. (2015). Universitetskaia klinika: kakuiu model vozmet za obrazets Ukraina? Available at: https://www.vz.kiev.ua/ $\mathrm{ru}$ /universitetska-klinika-yaku-model-vizme-za-vzirec-ukrayina/

16. Ozminkowski, R. J., Dunn, R. L., Goetzel, R. Z., Cantor, R. I. Murnane, J., Harrison, M. (1999). A Return on Investment Evaluation of the Citibank, N.A., Health Management Program. American Journal of Health Promotion, 14 (1), 31-43. doi: http:// doi.org/10.4278/0890-1171-14.1.31

17. Dovhan, L. Ye., Malyk, I. P., Mokhonko, H. A., Shkrobot, M. V. (2017). Menedzhment orhanizatsii. Kyiv: KPI im. Ihoria Sikorskoho, 271.

18. Shtepenko, K. P., Borisova, T. I. (2019). Status of voluntary medical insurance in the context of consideration of the activities of insurance companies. Efektyona Ekonomika, 2. doi: http:// doi.org/10.32702/2307-2105-2019.2.43

19. Naukovo-pravovyi dyskurs shchodo problem ta perspektyv zaprovadzhennia v Ukraini oboviazkovoho medychnoho strakhuvannia. Available at: https://coordynata.com.ua/naukovo-pravovij-diskurssodo-problem-ta-perspektiv-zaprovadzenna-v-ukraini-obovazkovogo-medicnogo-strahuvanna

Iaroslava Levchenko, PhD, Associate Professor, Department of Economics and Entrepreneurship, Kharkiv National Automobile and Highway University, Kharkiv, Ukraine, ORCID: https://orcid.org/ 0000-0002-4979-1101, e-mail: slavalevcenko1984@gmail.com

Nataliya Solopun, PhD, Associate Professor, Department of Economics and Entrepreneurship, Kharkiv National Automobile and Highway University, Kharkiv, Ukraine, ORCID: https://orcid.org/0000-00028958-9303, e-mail: solopunnataliya@gmail.com 